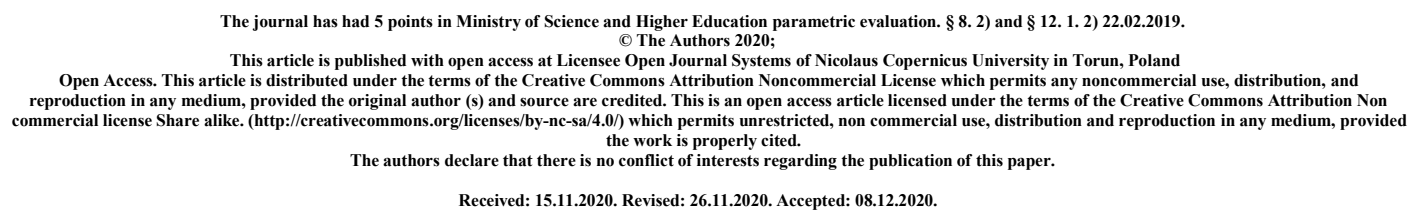

\title{
Maternal hypothyroidism in the perinatal period and child development
}

Niedoczynność tarczycy u matki w okresie prenatalnym a rozwój dziecka

\section{Agnieszka Strączyńska}

Department of Physiotherapy, Collegium Medicum in Bydgoszcz, Nicolaus Copernicus University in Toruń

\begin{abstract}
Thyroid hormones are essential growth and development regulators in both foetal and neonatal period. They are involved in metabolic processes, in maturation of nerve and skeletal tissue and many other fluid tissues. Abnormalities in their function during foetal development may have an impact on disorders in pregnancy, or increase susceptibility to the occurrence of neurodevelopmental disabilities in children later in life. There are many observational and epidemiological studies investigating the relationship between maternal thyroid dysfunction and a child development, yet a discussion on the subject is ongoing and robust evidence for its existence is still lacking.
\end{abstract}

Key words: thyroid dysfunction, maternal hypothyroidism, child development

\section{Streszczenie}

Hormony tarczycy są ważnymi regulatorami wzrostu i dojrzewania w okresie zarówno płodowym jak i niemowlęcym. Biorą udział $w$ procesach metabolicznych, dojrzewania tkanki nerwowej, szkieletowej i wielu innych tkanek ustroju. Nieprawidłowości w ich działaniu podczas rozwoju płodu mogą mieć wpływ na zaburzenia w okresie ciąży czy zwiększyć podatność na późniejsze wystąpienie zaburzeń neurorozwojowych $\mathrm{u}$ dzieci. Pomimo, iż istnieje wiele badań obserwacyjnych i 
epidemiologicznych, które opisują związek między dysfunkcją tarczycy u matki a rozwojem dziecka nadal trwa dyskusja na ten temat i wciąż brakuje rzetelnych dowodów na ich istnienie.

Słowa kluczowe: zaburzenia tarczycy, matczyna niedoczynność tarczycy, rozwój dziecka

\section{Introduction}

Maternal hypothyroidism (MHT) in the perinatal period is one of the most frequent pregnancy complications. In respect of various thyroid hormone concentrations, we distinguish the following three subtypes: overt hypothyroidism $(\mathrm{OH})$, subclinical hypothyroidism $(\mathrm{SCH})$ and isolated hypothyroidism $(\mathrm{IH})$ [1][2]. It is still under discussion whether incidence of MHT leads to more adverse impacts on the mother or foetus. Some research indicates that MHT might be a potential cause of certain pregnancy or childbirth disorders. It has been observed that pregnant women with MHT are at increased risk of developing numerous foetal dysfunctions or delivering newborn infants with laterlife disorders referring to neuropsychological development [1][3]. Material thyroid dysfunction in pregnancy is associated with an adverse effect on the infant already in utero and in the postnatal period, particularly if the dysfunction occurs in the early stages of pregnancy [4][5]. As reported by recent experimental and observational studies, maternal hypothyroidism (low thyroxine (T4) with a correct concentration of the thyroid stimulating hormone (TSH)) in early pregnancy might be related to impairments of brain development in the baby. In addition to that a correlation was noticed between maternal hypothyroidism in early pregnancy and poor results in infant neurodevelopmental assessment scales at eight months, four and seven years of age [6]. Haddow et al. found lower score in intelligence testing, attention and concentration tests, and in tests of visual-motor skills in children at eight years of age among the group of 48 mothers with an untreated hypothyroidism (defined as levels TSH $>99.7$ th percentile or a TSH measured between 98 and 99.6 percentile and total T4 $<7,75 \mu \mathrm{g} / \mathrm{dL}$ ) at the 17 th week of pregnancy against 124 children in the control group [7]. In his study, Leger et al. submitted evidence that hypothyroidism in pregnancy may be a risk factor for neurodevelopmental impairments [8]. This confirmed, as evidenced in earlier studies, that there is a link between maternal hypothyroidism dysfunction and a potential risk of the occurrence of adverse developmental milestones within one year in the offspring [9][10]. Their research revealed there is a correlation between poor motor and communication skills within one year for a child and achieving at least one 
serum TSH concentration $\geq 10 \mathrm{mIU} / \mathrm{L}$ in the first trimester of pregnancy [8]. Further, Leger et al. demonstrated that high serum TSH concentrations (TSH $\geq 10 \mathrm{IU} / 1$ ) within the first three to six months of pregnancy were associated with a higher risk of preterm delivery and foetal macrosomia [8]. Several studies also indicate adverse outcomes of hypothyroidism in pregnancy, such as: maternal anaemia, gestational hypertension, gestational diabetes, placental abruption, pre-eclampsia and stillbirths [11]. It is considered that women known to have had hypothyroidism in past pregnancies are at higher risk of gestational diabetes in subsequent pregnancies [12]. However, certain available research showed no influence of SCH in mothers, in particular, on neurodevelopment in their offspring [13].

In summary, it can be easily stated that maternal hypothyroidism may negatively impact pregnancy complications, whereas a relation of psychomotor developmental disorder in children has still been insufficiently researched and not fully understood.

\section{Thyroid hormone regulation in foetal life}

Thyroid hormones (TH) play a key role in the growth and maturity process both in the foetal and infant period. They are involved in metabolic processes, in maturation of nerve and skeletal tissue and many other fluid tissues [14][15]. The thyroid is the first endocrine gland in the organism that develops around the third week of pregnancy. It arises from pharyngeal pouches that are composed of endoderm. Thyroid development begins as a pharyngeal diverticulum from the primitive pharynx. Then, the diverticulum descends to reach destination in the neck. During the descent, the thyroid connects to the tongue by the thyroglossal duct. The thyroid originates between the first and second esophageal pouch near the base of the tongue [16][17]. At the third week of pregnancy, around days 20-24, endodermal cells of the primitive pharynx proliferate creating thyroid diverticulum. Starting from the 5th week of pregnancy, the thyroid diverticulum migrates caudally along the centre line, crossing to the front to the hyoid bone and laryngeal cartilage [17][18]. In early descent, the thyroid is hollow, but then during migration it hardens forming vesicular elements of the thyroid gland. Division of the thyroid to the right and left lobe occurs at the 5th week of pregnancy. At the 7 th week of pregnancy, the thyroid reaches the destination in pretracheal position on the neck below the thyroid cartilage of the larynx. Thyroid follicles form around day 70 in foetal life [16][18]. Growth of the thyroid is influenced by growth factors coordinated by different transcription factors [18]. Iodine concentration is found in thyroid follicles at weeks 10-12 in foetal life, and as early as at that stage thyroglobulin can be measured. In addition, thyroid hormones could already be determined in a foetal serum. Their concentration increases in proportion to foetal age and stabilises between 27 and $28 \mathrm{WG}$ [19][20]. TH hormone synthesis (by iodination of tyrosine thyroglobulin residues) occurs in thyroid follicles. A thyroid-stimulating hormone (TSH) regulates iodine uptake by the thyroid. If required, thyroglobulin is endocytosed and degraded by lysosomal enzymes to triiodothyronine (T3), an active hormone and thyroxin (T4), a prohormone. Availability of T3 and T4 in cells is regulated by the 
iodothyronine deiodinase enzymes found as 3 isoforms (D1, D2 and D3) via extracting specific iodine atoms from TH [21]. The control mechanism of thyroid secretion activity is a mechanism of negative feedback loop that partially results from the influence of $\mathrm{TH}$ on hypothalamus and a direct impact on hypophysis. T3 and T4 inhibit the TSH secretion affected by TRH [22][23] TH, which are synthesised by maternal thyroid, and cross the placenta through specific thyroid hormone transporters. They are more selective for maternal $\mathrm{T} 4$ that is converted into $\mathrm{T} 3$ and reverse triiodothyronine (rT3) by placental deiodinases [24]. Then, maternal T3 can reach foetal tissue prior to thyroid maturation. Iodothyronine deiodinases activate and deactivate TH. D1 (type 1 deiodinase) during adult life results in converting T4 into T3 (merely active in foetal life), D2 (type 2 deiodinase) is converting T4 into T3, whereas D3 (type 3 deiodinase) changes T4 to rT3. Both are present in foetal brain and are categorised as inactivating enzymes. In addition, D3 protects the foetus from elevated maternal T4 level. These mechanisms are of critical importance in the case of either maternal or child hypothyroidism, as they protect the foetus from via a lower T3 concentration that might have a considerable significance for tissue development and differentiation [24][25].

\section{Maternal hypothyroidism}

Major alterations occur in the thyroid physiology during pregnancy. Demand for maternal TH substantially increases in pregnancy. Human chorionic gonadotropin (HCG) produced by the placenta directly stimulates a TSH receptor causing increase in TH production. Consequently, it causes a slight temporary increase in fT4 with a reverse decrease in a TSH in the first trimester of pregnancy. Therefore, to maintain the adequate fT4 level, more TH release is necessitated [26][27]. Maternal hypothyroxinemia is diagnosed when the TSH level is normal, yet fT4 level remains abnormally low. It typically progresses due to iodine deficiency, however numerous studies show it arises as a result of environmental disorders, obesity, iron deficiency and angiogenic disorder factors [28]. It should also be mentioned that a slight iodine deficiency, including subclinical hypothyroidism, is considered to be one of the most common causes of maternal hypothyroxinemia [29] $\mathrm{SCH}$ is defined as an increased thyroid-stimulating hormone (TSH) concentration in a serum, in the context of normal concentration of triiodothyronine (T3) and tetraiodothyronine (T4) [30]. Furthermore, SCH is not often characterised by clinical symptoms of hypothyroidism, and if so they are mildly expressed [31]. It could also account for transition period to a full-blown expression of hypothyroidism. It has been demonstrated that more elevated TSH starting concentration means higher likelihood of developing hypothyroidism [32]. Consequences of hypothyroidism in pregnant women and in children born to mothers with hypothyroidism are indisputable, nevertheless various pathological conditions that still occur are inconsistent. Existing data suggest there is a concern between prevalence of $\mathrm{SCH}$ and a risk of preterm delivery, pregnancy loss, hypertension and pre-eclampsia, gestational diabetes, or intrauterine growth restriction [7][33]. Not only does maternal hypothyroidism in the perinatal period impact the course of 
pregnancy, but the child itself as well. The relation between thyroid hormone deficiency in pregnancy and its effect on foetal development has been investigated for many years. Unfortunately due to a multifactorial etiology of both thyroid disorders and neurodevelopmental impairments in infants, the study of its correlation constitutes a complex and highly debatable subject.

\section{Effect of maternal hypothyroidism on the psychomotor development of the offspring}

Brain development in the baby is a complex process that initiates in early foetal period and continues as intensely after birth. Foetal brain development consists of a series of various stages and is highly susceptible to a mother's environment [15]. It is widely acknowledged that there is a connection between a normal level of thyroid hormones and processes of gene and protein expression related to the appropriate development of the central nervous system [34]. Findings indicate that gene expression in the developing brain may be subject to changes under conditions of T4 deficiency [35]. Maternal TH supply protects early brain development in child in foetal age predominantly through conversion of maternal fT4 via D2 [36]. Hence, brain sections in child that could be affected by maternal hypothyroidism or congenital hypothyroidism in infant $(\mathrm{CH})$ are the ones mainly responsible for spatial and associative memory, language and auditory processing, but for attention and executive processing as well. Research also shows that the absence of TH in the first trimester of pregnancy could contribute to future impairments of motor skills, visual processing and memory of events [37]. Studies by Henrichs et al. demonstrated a rise by $80 \%$ in the probability of developing a language delay at months 18 and 30 in children whose mother had free T4 levels $<10$ percentile at the 13th week of pregnancy [38]. Another observational study by Haddow et al. found that amid infants born to women afflicted by untreated hypothyroidism in pregnancy, more children obtained a lower score in the full-scale IQ of intelligence testing for children ages 7-9 [7]. Furthermore, Li et al. analysed the development of children born to mothers both with hypothyroxinemia and subclinical hypothyroidism in the first stage of pregnancy. Both groups revealed a lower score in terms of mental and psychomotor development [39]. Pop et al., Cleary-Goldman et al., and Zhong et al. pointed out in three independent studies on maternal hypothyroidism disorders that children born to mothers with overthypothyroidism show a lower outcome of the physical and mental development, as well as a lower susceptibility to external stimuli in comparison with infants born to mothers with normal thyroid function [40-42]. Additionally, a thorough meta-analysis performed by the Liu team suggests that $\mathrm{SCH}$ is associated with delayed child intellectual and motor development. They scrutinised 15 available randomised clinical trials from inception to 2017 from more than 1000 various studies on maternal hypothyroidism focusing on $\mathrm{SCH}$ (most prevalent). Also, it should be taken into account that in this analysis the follow-up time in studies was only two years. Thus, the impact of maternal SCH in the long-term was not examined [43]. 
Although previous studies reported an association between clinical maternal hypothyroidism as well as mild hypothyroidism in the first stage of pregnancy and cognitive impairments in children, there are also publications that do not confirm the said hypothesis. Chevrieri et al. did not determine credible evidence for maternal hypothyroidism to be associated with the neurological development in children. Nevertheless, it is worth stressing at this point that examinations in question concerned the second period of pregnancy [6]. The discussion is still ongoing and credible evidence is still lacking as to whether there is a risk of adverse neonatal outcomes in the case of maternal hypothyroidism.

\section{Conclusions}

Maternal hypothyroidism impacts child development from the very beginning of foetal life. It affects a number of processes regarding the nervous system, cardiovascular system or musculoskeletal system. It is considered that only accurate screening, fast diagnosis and implementation of an appropriate comprehensive therapy could allow for proper future psychomotor development in children, and prevention of the adverse consequences. It is still required to conduct further clinical trial encompassing a vast number of participants and appropriate standardised classification so as to properly elucidate the significant correlation between thyroid disorders in mother and a foetal development.

\section{References}

1. Casey BM, Dashe JS, Spong CY, McIntire DD, Leveno KJ, Cunningham GF. Perinatal significance of isolated maternal hypothyroxinemia identified in the first half of pregnancy. Obstet. Gynecol. 2007; 109: 1129-1135.

2. Chen L-M, Chen Q-S, Jin G-X, Si G-X, Zhang Q, Ye E-I, Yang H, Cai L-Q, Peng M-M, Lin Z-Z, Yu L-C, Zhang C, Lu X-M. Effect of gestational subclinical hypothyroidism on early neurodevelopment of offspring. J Perinatol. 2015; 35:678-682.

3. Casey BM, Dashe JS, Wells CE, McIntire DD, Byrd W, Leveno KJ et al. Subclinical hypothyroidism and pregnancy outcomes. Obstet. Gynecol. 2005; 05: 239-245.

4. Korevaar TI, Muetzel R, Medici M, Chaker L, Jaddoe VW, de Rijke YB, Steegers EA, Visser TJ, White $\mathrm{T}$, Tiemeier $\mathrm{H}$ et al. Association of maternal thyroid function during early pregnancy with offspring IQ and brain morphology in childhood: a population-based prospective cohort study. Lancet Diabetes Endocrinol. 2016;4:35-43.

5. Alexander EK, Pearce EN, Brent GA, Brown RS, Chen H, Dosiou C, Grobman WA, Laurberg P, Lazarus JH, Mandel SJ et al. Guidelines of the American Thyroid Association for the diagnosis and management of thyroid disease during pregnancy and the postpartum. Thyroid 2017; 27: 315389. 
6. Chevrier J, Harley KG, Kogut K, Holland N, Johnson C, Eskenazi B. Maternal Thyroid Function during the Second Half of Pregnancy and Child Neurodevelopment at 6, 12, 24, and 60 Months of Age. J Thyroid Res 2011; 2011:426427.

7. Haddow JE, Palomaki GE, Allan WC, Williams JR, Knight GJ, Gagnon J et al.Maternal thyroid deficiency during pregnancy and subsequent neuropsychological development of the child. N Engl J Med 1999; 341: 549-555.

8. Leger J, dos Santos S, Larroque B \& Ecosse E. Pregnancy outcomes and relationship to treatment adequacy in women treated early for congenital hypothyroidism: a longitudinal population-based study. J Clin. Endocrin. Metab. 2015;100:860-869.

9. Ghassabian A, Henrichs $J$ \& Tiemeier H. Impact of mild thyroid hormone deficiency in pregnancy on cognitive function in children: lessons from the Generation R Study. Best Practice and Research: Clin. Endocrin. Metab. 201428 221-232.)

10. Smit BJ, Kok JH, Vulsma T, Briet JM, Boer K \& Wiersinga WM.Neurologic development of the newborn and young child in relation to maternal thyroid function. Acta Paediatrica $200089291-$ 295

11. Rashid M, Rashid MH. Obstetric management of thyroid disease. Obstet Gynecol Surv 2007; 62: 680-688; quiz 691. Nelson DB, Casey BM, McIntire DD, Cunningham FG. Subsequent Pregnancy Outcomes in Women Previously Diagnosed with Subclinical Hypothyroidism. Am J Perinatol 2013; 31: 77-84.

12. Nelson DB, Casey BM, McIntire DD, Cunningham FG. Subsequent Pregnancy Outcomes in Women Previously Diagnosed with Subclinical Hypothyroidism. Am J Perinatol 2013; 31: 77-84.

13. Behrooz HG, Tohidi M, Mehrabi Y, Behrooz EG, Tehranidoost M, Azizi F. Subclinical hypothyroidism in pregnancy: intellectual development of offspring. Thyroid 2011;21: 11431147.

14. Senese R, Cioffi F, de Lange P, Goglia F, Lanni A. Thyroid: biological actions of 'nonclassical' thyroid hormones. J Endocrinol. 2014 Apr;221(2):R1-12.

15. Moog NK, Entringer S, Heim C, Wadhwa PD, Kathmann N, Buss C. Influence of maternal thyroid hormones during gestation on fetal brain development. Neuroscience. 2017 Feb; 342:68100.

16. De Felice M., Di Lauro R.: Thyroid development and its disorders: Genetics and molecular mechanisms. Endocrine Rev., 2004:25, 722.

17. Shivdasani R.: Molecular regulation of vertebrate early endoderm development. Dev. Biol., 2002:249, 191.

18. Takanashi Y., Honkura Y., Rodriguez-Vazquez J.F. et al.: Pyramidal lobe of the thyroid gland and the thyroglossal duct remnant: A study using human fetal sections. Ann. Anat., Jan. 2015:197, 2937. 
19. Burrow G.N., Fisher D.A., Larsen P.R. Maternal and fetal thyroid function. N. Engl. J. Med., 1994:331(16), 10721078

20. Hume R., Simpson J., Delahunty C. et al.: Human fetal and cord serum thyroid hormones: developmental trends and interrelationships. J. Clin. Endocrinol. Metab., 2004:89(8), 4097-4103.

21. Kumar P, Mohan V, Sinha RA, Chagtoo M, Godbole MM. Histone deacetylase inhibition reduces hypothyroidism-induced neurodevelopmental defects in rats. J Endocrinol. 2015 Nov;227(2):8392.

22. Glinoger D, et al.: Regulation of maternal thyroid during pregnancy. J. Clin. Endocrinol. Metab., 1990; 71: 276-287.

23. Préau L, Le Blay K, Saint Paul E, Morvan-Dubois G, Demeneix BA. Differential thyroid hormone sensitivity of fast cycling progenitors in the neurogenic niches of tadpoles and juvenile frogs. Mol Cell Endocrinol. 2016;1;420:138-51.

24. Prezioso G, Giannini C, Chiarelli F. Effect of Thyroid Hormones on Neurons and Neurodevelopment. Horm Res Paediatr 2018; 90:73-81

25. Beń-Skowronek. The development of children from mothers with thyroid disorders. Pediatr Endocrinol 2015; 14(1):53-58.

26. Burrow GN, Fisher DA \& Larsen PR. Maternal and fetal thyroid function. N Engl J Med 1994; 331:1072-1078.

27. Glinoer D. The regulation of thyroid function in pregnancy: pathways of endocrine adaptation from physiology to pathology. Endocrin. Rev 199718 404-433

28. Dosiou C, Medici M. Management of endocrine disease: isolated maternal hypothyroxinemia during pregnancy: knowns and unknowns. Eur J Endocrinol. 2017 Jan; 176(1):R21-38.

29. Vermiglio F, Lo Presti VP, Moleti M, Sidoti M, Tortorella G, Scaffidi G, Castagna MG, Mattina F et al. Attention deficit and hyperactivity disorders in the offspring of mothers exposed to mildmoderate ID: a possible novel ID disorder in developed countries. J Clin Endocrinol Metab 2004;89:6054-6060

30. Zhang Y, Fan Y, Yu X, Wang X, Bao S, Li J, Fan C, Shan Z, Teng W. Maternal subclinical hypothyroidism impairs neurodevelopment in rat offspring by inhibiting the CREB signaling pathway. Mol Neurobiol 2015;52:432-441.

31. Zdrojowy-Wełna A., Rogala N., Zatońska K, Bednarek-Tupikowska G. Management of subclinical hypothyroidism in pregnancy and in children. Fam Med Primary Care Rev. 2015;17(1):60-65.

32. Kabadi UM: Subclinical hypothyroidism, Arch Int Med 1993, 153, 957-961.

33. Pop VJ, Kuijpens JL, van Baar AL, Verkerk G, van Son MM, de Vijlder JJ et al. Low maternal free thyroxine concentrations during early pregnancy are associated with impaired psychomotor development in infancy. Clin Endocrinol (Oxf) 1999; 50: 149-155. 
34. Bernal J. Thyroid hormone regulated genes in cerebral cortex development. J Endocrinol. 2017;232: R83-R97.

35. Sinha RA, Pathak A, Mohan V, Bandyopadhyay S, Rastogi L, Godbole MM (2008) Maternal thyroid hormone: a strong repressor of neuronal nitric oxide synthase in rat embryonic neocortex. Endocrinology 149(9):4396-4401

36. Kester MH, Martinez de Mena R, Obregon MJ, Marinkovic D, Howatson A, Visser TJ et al. Iodothyronine levels in the human developing brain: major regulatory roles of iodothyronine deiodinases in different areas. J Clin Endocrinol Metab. 2004 Jul;89(7):3117-

37. Rovet JF. The role of thyroid hormones for brain development and cognitive function. Endocr Dev. 2014;26:26-43.

38. Henrichs J, J. J. Bongers-Schokking, J. J. Schenk et al.,Maternal thyroid function during early pregnancy and cognitive functioning in early childhood: the generation R study. J Clin Endocrinol Metab. 2010; 95(9): 4227-4234.

39. Y. Li, Z. Shan, W. Teng et al., bnormalities of maternal thyroid function during pregnancy affect neuropsychological development of their children at 25-30 months. Clin Endocrinol. 2010;72 (6): $825-829$.

40. Pop VJ, Brouwers EP, Vader HL, Vulsma T, van Baar AL, de Vijlder JJ. Maternal hypothyroxinaemia during early pregnancy and subsequent child development: a 3-year follow-up study. Clin Endocrinol (Oxf) 2003;59:282-288.

41. Cleary-Goldman J, Malone FD, Lambert-Messerlian G, Sullivan L, Canick J, Porter TF, Luthy D, Gross S, Bianchi DW, D'Alton ME. Maternal thyroid hypofunction and pregnancy outcome. Obstet Gynecol 2008;112:85-92.

42. Zhong XM, Wu JL. Clinical analysis on maternal hypothyroidism during pregnancy. Med J West China 2008;20:604-605.

43. Liu Y, Chen H, Jing C, Li FP. The association between maternal subclinical hypothyroidism and growth, development and childhood intelligence: a meta-analysis. J Clin Res Pediatr Endocrinol 2018; 10 (20):153-161. 